\title{
Patryk Tomaszewski
}

\section{Dzialalność i ideologia Zwiazku Synarchicznego w latach 1924-1939}

Odzyskanie niepodległości przez Polskę w roku 1918 przyczyniło się w znaczącym stopniu do rozwoju myśli politycznej różnego rodzaju grup i organizacji. Jednym $\mathrm{z}$ takich środowisk byli synarchiści ${ }^{1}$.

Słowo synarchia pochodzi $\mathrm{z}$ języka greckiego i oznacza dosłownie wspólrządy (od gr. sýn - razem i árchein-panować, rządzić). Pojęcie to jest jednoznaczne wyłącznie w sensie etymologicznym (jako antonim do słowa „anarchia”). W myśli politycznej oznacza ustrój polityczny polegający na usunięciu sprzecznych dążen społecznych i zwalczających się stronnictw przez wprowadzenie hierarchii społecznej, na podstawie zasług obywatelskich oraz równości wobec prawa ${ }^{2}$. Samo określenie synarchia używane było początkowo przez Martynistów francuskich ${ }^{3}$. Idea ta związana była z poglądami mówiącymi o możliwości syntezy różnych religii. Głównym przedstawicielem idei stworzenia synkretycznego kościoła uniwersalnego był kabalista i martynista Saint-Yves D'Alveydre (1842-1909).

Synarchia w rozumieniu polskich ideologów tego nurtu oznaczała syntezę różnych kierunków społecznych. Wedhug polskich synarchistów w systemie tym miało dojść do harmonijnej współpracy „wszystkich

'O synarchistach pisal W. Roszkowski, Synarchiści Polski międzywojennej, Przegląd Powszechny, nr 5-6, 1983, s. 262-277. Tekst niniejszy stanowi próbę calościowego ujęcia i rozszerzenia niektórych ustaleń W. Roszkowskiego.

${ }^{2}$ Slownik Wyrazów Obcych, Trzaska, Evert, Michalski, Warszawa 1939, kol. 2080.

${ }^{3}$ W. Roszkowski, Synarchissci.., s. 262. 
warstw pomiędzy sobą w imię ogólnego dobra całego narodu"4. Ideolodzy synarchizmu zgrupowali się wokół środowisk wywodzących się $z$ kręgów polskiej masonerii okultystycznej.

W Polsce prekursorem synarchizmu byl publicysta i literat, thumacz dziel Józefa Marii Hoene-Wrońskiegos, założyciel i prezes powstałego w 1919 roku w Warszawie Instytutu Mesjanistycznego im. Hoene-Wrońskiego - Józef Jankowski (1865-1935) ${ }^{6}$.

Na czele synarchistów od momentu powstania Polskiego Związku Synarchicznego, dnia 21 V 1924 r. w Warszawie ${ }^{7}$ (nazwę Polskiego Związk. Synarchicznego zmieniono dnia 29 VIII 1928 r. na Związek Synarchiczny $^{8}$ ), aż do wybuchu II wojny światowej stał Wlodzimierz Tarło-Maziński (1889-1967) ${ }^{9}$. Ten działacz synarchiczny był z wykształcenia inżynierem radiotechniki, a także podpulkownikiem rezerwy Wojska Polskiego. Początkowo służył w armii rosyjskiej. W 1917 roku przeszedł do I Korpusu gen. Józefa Dowbór-Muśnickiego (ten w swoich wspornnieniach wydanych w 1935 r. pisał - iż Tarło-Maziński wówczas ,grawitowal do komunizmu"10). Po przybyciu do kraju, w 1918 r., zostal szefem oddziału techniki wojskowej przy Sztabie Generalnym Wojska Polskiego

${ }^{4}$ Co to jest synarchia, Warszawa 1925, s. 5 .

5 J. M. Hoene-Wroński (1776-1853), wynalazca, matematyk, filozof - mesjanista.

${ }^{6}$ W. Roszkowski, op.cit., s, 262; R. Taborski, Jankowski Józef, [w:] Polski Stownik Biograficzny, t. XI, s. 543.

${ }^{7}$ Synarchja w ustroju politycznym polski, Warszawa 1929, s. 61.

8 Ibidem.

${ }^{9}$ W. Tarło-Maziński, przed przekroczeniem granicy rumuńskiej wraz z wojskami polskimi w drugiej polowie września 1939 roka, przekazal kierowniciwo krajowej organizacji AMORC Stanisławowi Goszczyńskiemu, zaś kierownictwo Związku Synarchicznego oddał w reece Stefana Pachnowskiego - oficjalnego prezesa tolerowanego przez Niemców Warszawskiego Wojewódzkiego Komitetu Pomocy Społecznej. Po aresztowaniu Pachnowskiego (przedwojenny prezydent Włocławka i założyciel Polskiej Partii Radykalnej, za: W. Roszkowski, Synarchiści..) w 1942 roku przez Gestapo, na czele Związku Synarchicznego stanąl, $z$ inicjatywy B. Whodarza, ezoteryk, adwokat dr Wacław Dunin-Goździkowski. Synarchiści opracowali wówczas program „Wytyczne dla organizacji państwa, opartego na wspólpracy całego narodu". Z synarchistami związane byly wtedy podziemne pisma: „Na Odwiecznym Szlaku Polski", „Herold Polski”, „Promień a także redagowany przez W. Dunina-Goździkowskiego „Monitor” oraz „Dzień Warszawy”. Za: L. Hass, Zasady w godzinie próby. Wolnomularstwo w Europie Srodkowo-Wschodniej 1929-1941, Warszawa 1987, s. $260-261$.

${ }^{10}$ W. Roszkowski, op. cit., s. 262. 
w Lublinie. $Z$ czasów służby wojskowej pochodzą jego podręczniki wydane $\mathrm{w}$ języku rosyjskim "Zapiski do radiotelegrafii" (Piotrogród 1915 r.), „Elementarnija radiotelegrafija” (Piotrogród 1917 r.) oraz wydane po polsku „Elementarna radiotelegrafia i radiotelefonia, z pobieżnym kursem elektrotechniki" (Mińsk Litewski-Kijów 1917 r.), a także, będące pierwszym polski podręcznikiem radiotelegrafii wojskowej, wydane w 1919 r. „Zasady radiotelegrafii". W niepodległej Polsce Maziński ukończył kurs wyższej administracji przy Uniwersytecie Warszawskim i kurs dyplomatyczny przy Szkole Nauk Politycznych. Po przejściu do rezerwy był inspektorem szkolnym okręgu białostockiego oraz założycielem i kierownikiem gimnazjum Towarzystwa Szkół Pracy Twórczej. Wykładal w kilku gimnazjach w Warszawie, tu też założyl Liceum Przemysłowo-Techniczne. W 1933 roku obronił dysertacje doktorską z filozofii na Uniwersytecie Warszawskim. W czasie II wojny światowej Maziński mieszkał we Francji, gdzie był wykładowcą polskiego Gimnazjum i Liceum im. C. Norwida w Villard de Lans kolo Grenoble. Po roku 1945 powrócil do Polski, zostal naczelnikiem wydziału spraw konsularnych w Ministerstwie Spraw Zagranicznych, a także prezesem Komitetu Opieki nad Polakami za Granica. Tarło-Maziński był także znanym Polskim ezoterykiem, mesjanistą i syntetycznym okulysta. W latach 1921-1923 redagowak miesięcznik ,Wiedza Filozoficzna - miesięcznik poświęcony materiałon wiedzy syntetycznej i uprawie filozoficznej słowa polskiego", w znacznej części poświecony twórczości Hoene-Wrońskiego. Od roku 1924 byl prezesem Towarzystwa Miłośników Wiedzy i Przyrody, związany z Różokrzyżowcami (imię zakonne: Sa-Amon-Ra), od roku 1932 stał na czele odłamu Różokrzyżowców Starożytnego Mistycznego Zakonu Róży i Krzyża (The Ancient Mystical Rosae Order Crusis - AMORC), a w roku 1934 otrzymal generalne przedstawicielstwo FUDOSI (Fédération Universelle des Ordres et Sociétés Initiatiques) na Polskę - stał się zwierzchrikiem nad działającymi w niej szkołami i organizacjami ezoterycznymi. W swoim mieszkaniu w Warszawie mial sporych rozmiarów ,świątynię" zbudowaną wedlug regul ,sztuki masońskiej". Będąc we Francji byl jednym z założycieli Loży „Kopenik" ",I! Na początku działalności synarchistów czołową rolę w ruchu odgrywali obok Mazińskiego: Sekretarz Generalny

${ }^{11}$ J. Kubiatowski, Tarto-Moziniski Whodzimierz, [w:] Polski Slownik Biograficzny, t. XX, s. 300-302; L. Hass, Masoneria Polska w $X X$ w. Losy, ludzie, loże, Warszawa 1993, s. 251-252; J. Nadlewicz-Kremky, Kim jest nasz synarcha $w d u c h u$, Synarchista, nr 2, VIII 1936, s. 2-4. 
- Jan Barchwic (wspólnie z innym działaczem związku Mieczysławem Wielbikiem pisywał do czasopisma mesjanistycznego „Wiedza i Przyroda" ${ }^{12}$ ) oraz Dyrektor Zarządu Głównego - Marian Pajor ${ }^{13}$.

Do czołowych działaczy Związu Synarchicznego zaliczyć należy powieściopisarza i publicystę, pracownika Ministerstwa Spraw Zagranicznych oraz prezesa Ligi Morskiej i Kolonialnej w Warszawie Gustawa Olechowskiego ${ }^{14}$, ponadto senatora i mesjanistę Gustawa Dobruckiego ${ }^{15}$, ubezpieczeniowca Antoniego Doermana, senatora Stanisława Goszczyńskiego ${ }^{16}$, ppłka rezerwy Mariana Hoffa, Stanisława Jabłońskiego, Wacława Kalabińskiego, entomologa i filozofa Janusza NadelewiczKremkyego, mesjanistę i teozofa Antoniego Leparskiego, publicystów Leona Mikolajczaka, Franciszka Młynarskiego, Władysława Piotrowskiego, dra Jerzego Kurczyńskiego, „Sodalis Marianusa” Wojciecha Rzadkowskiego, a także twórce programu gospodarczego synarchistów inż. Feliksa Sobolewskiego ${ }^{17}$. Prawdopodobnie poza statutowymi cialami Związku Synarchicznego istnial powołany przez Mazińskiego, zakon-

${ }^{12}$ Do „Wiedzy i Przyrody" pisywał również Włodzimierz Tarło-Maziński, a także Józef Jankowski. Zob. A. Roszkowski, Mesjanizm a masoneria okultystyczna w Drugiej Rzeczypospolitej, Przegląd Powszechny, nr 2, 1983, s. 209 $-224$.

13 W. Roszkowski, op.cit., s. 263. W roku 1926 na czele związku obok Mazińskiego stali jako Sekretarz Generalny Rady Naczelnej - Marian Pajor oraz Dyrektor Zarządu Glównego - Janusz Kremky (kupiec i przemysłowiec, radny i czlonek Prezydium Rady miasta Warszawy). Zob. Synarchista, nr 1, z 15 XI 1926, s. 5; Synarchista, no 5, V 1929, s. 15.

14 M. Tyrowicz, Olechowski Erazm Gustaw, [w:] Polski Slownik Biograficzry, t. X, s. 734-737.

is Dobrucki Gustaw Karol (1973-1943), lekarz, Prezes Stronnictwa Demokratyczno-Narodowego w Stanisławowie, później przewodniczący Związku Strzeleckiego, lekarz POW, nalezał do PSL "Piast" później PSL „Jedność Ludowa". W 1927/1928 minister wyznań religijnych i oświecenta publicznego. Senator RP pierwszej kadencji 1922-1927. Zob. Poslowie i Senatorowie Rzeczypospolitej Polskiej 1919-1939. Slownik biograficzny, t. I, pod. red. M. Smogorzewska, Warszawa 1998, s. 328-329.

${ }^{16}$ S. Goszczyński (1875-1965) - dyrektor i właściciel kilku fabryk, członek klubu PSL „Wyzwolenie”, następnie wspólzałożyciel Klubu Pracy, a od 1928 roku członek BBWR. Czlonek Wielkiej Loży Narodowej. Zob. Poslowie i Senatorowie Rzeczypospolitej Polskiej 1919-1939, Slownik biograficzny, t. I, pod red. M. Smogorzewska, Warszawa 2000, s. 88-89.

${ }^{17}$ Biuletyn Polityczny, nr 2-3, 1927, s. 681. F. Sobolewski ur. 1 V 1887 r., zm. 23 IX 1929, był autorem określenia Towarowa Jednostka Obliczeniowa, o której będzie mowa w dalszej części artykuła. 
spirowany wyższą instancją Związek Rycerstwa Duchowego, złożony wyłącznie $\mathrm{z}$ różokrzyżowców ${ }^{18}$.

Związek Synarchiczny mimo tego, iż był organizacją nieliczna, wykazywał się sporą aktywnością. Działacze tej organizacji wydali w latach 1924-1939 pokaźną ilość broszur i książek programowych. Do ważniejszych zaliczyć należy następujące pozycje: A. Leparski „Moralna odbudowa narodu", Łomża 1925; "Co to jest synarchia", Warszawa 1925; „Reformy ustroju pieniężnego", Warszawa 1926; „Synarchiczna reforma gospodarcza”, Warszawa 1927; „Synteza kierunków społecznych”, praca zbiorowa pod redakcja W. J. Rzadkowskiego, J. Kurczyńskiego, Poznań 1928; „Synarchia w ustroju politycznym Polski”, Warszawa 1929; M. Wielbik, „Rzut oka na przyszłość ustroju synarchicznego”, Warszawa 1932; „Konstytucja synarchiczna, materiały, uzasadnienia i plan konstrukcyjny”, Warszawa 1934; „Uniwersal Synarchistyczny”, Warszawa 1937. Z synarchistami zwiazany byl humorysta i publicysta "Kolców" i „Kuriera Codziennego” - Wojciech Karśnicki (1870-1940), który ze względu na szantaz, jakiego dopuścil się wobec aktorki operetkowej, zostal zbojkotowany ptzez środowisko dziennikarskie ${ }^{19}$. On to również w duchu synarchicznym napisał broszurę ,Kto chce rzeczywiście potężnej i bogatej Polski?", wydaną w Warszawie w 1927 *.

Od listopada 1926 roku Związek Synarchiczny wydawał również pismo „Synarchista", jak oznajmiał podtytuk, ,poświęcone budzeniu myśli i sumienia spolecznego". Pismo to wydawano nieregulamie. Początkowo kierowane bylo przez W. Piotrowskiego, a w póżniejszym czasie przez J. Kurczyńskiego, G. Olechowskiego, J. Nadelewicz-Kremkyego i W. Sokołowska. Ostatni numer ukazał się 15 sierpnia 1939 roku.

Zwiazek Synarchiczny, poza wydawaniem pisma i broszur programowych, rozpowszechnil kilka odezw, min.: „Odezwę do ogólu polskiego nauczycielstwa"20, „Orędzie do ludu"21. Ponadto w siedzibie Związku Synarchicznego przy ul. Brackiej 18, przez cały okres działalności zwiazkkı odbywały się odczyty mające na celu popularyzację idei synarchicznej. W roku 1926 wyshuchano następujących odczytów: „Stosunki współczesne w świetle rozwoju cywilizacji: „Zdobycze wiedzy i praktyka życia",

${ }^{18}$ L. Hass, Ambicje, rachuby, rzeczywistośc, wolnomularstwo w Europie Srodkowo Wschodniej 1905-1928, Warszawa 1984, s. 315.

${ }^{19}$ Zob. C. Gajkowski, Karśnicki Wojciech, [w:] Polski Slownik Biograficzny, t. XII, s. 143-144.

${ }^{20}$ Odezwa do ogólu polskiego nauczycielstwa, Synarchista, nr 1, 15 XI 1926, s. 5-6.

${ }^{21}$ Synarchista, nr 9, XI 1937, s. 9. 
„Zagadnienie pieniądza”, „Burżuazja i proletariat”, „Filozofia i religia”, "Przyjęcie drogowskazu dla rzeczywistości postępu narodu i ludzkości", „Przyczyny prądów rewolucyjnych i środki zaradcze”22. W kolejnych latach Związek Synarchiczny nadal organizował liczne prelekcje, nie tylko w stolicy. W styczniu 1929 r. Feliks Sobolewski wygłosil prelekcje dotycząca zagadnień gospodarczych w Związku Ziemian w Lipnie ${ }^{23}$. Natomiast przywódca związku nie ograniczył się do objazđów ze swoimi odczytami po kraju, ale również odwiedził Francję i Belgię, gdzie, jak przypuszcza W. Roszkowski, odbył prawdopodobnie spotkania $z$,euro pejską czołówką masonerii okultystycznej"24.

Przyglądając się organowi związku wyróżnić można kilka okresów w ich działalności. W początkowej fazie działalności synarchiści skupili się głównie na propagowaniu swojej ideologii. Dużo miejsca poświęcali kwestii dla nich zasadniczej, a więc całkowitej zmianie ustroju Rzeczypospolitej, w tym celu opowiadali się za zmianą ordynacji wyborczej oraz Konstytucji. Starając się rozszerzyć krąg zainteresowanych synarchizmem zwiazek proponowal powoływanie w terenie Klubów Synarchicznych $^{25}$. Zwiększenie aktywności synarchistów nastapiło po wydaniu w 1937 r. „Uniwersału Synarchicznego", adresowanego do szerokiej rzeszy odbiorców. Tezy zawarte w uniwersale uważane był przez synarchistów za bardzo cenne, ich wplyw intelektualny na społeczeństwo porównywali $z$ „Deklaracją Praw Człowieka”, czy też „Manifestem Komunistycznym"26. Dnia 17 XII 1937 r. dzialacze Związu Synarchicznego powołali do życia Konfederację Synarchiczna która miała zjednoczyć w swych szeregach grono organizacji, które podzielały założenia programowe zawarte w uniwersale. Do konfederacji zglosiło akces kilka niewielkich ugrupowań. Do Konfederacji Synarchicznej przystapila Polska Unia Demokratyczna, na czele której stal prezes Rady Glównej prof. A. Brodzic-Lipiński oraz sekretarz A. Gawron ${ }^{27} \mathrm{~W}$ programie PUD znajdowały się takie propozycje, jak: uwłaszczenie mas chłopskich zgodnie z wskazaniami Encykliki „Quadregesimo anno", roboty publiczne, unarodowienie przedsiębiorstw należących do „kapitału zagranicznego”, „odżydzenie handlu hurtowego"28. Ponadto do Konfederacji Synarchicznej

\footnotetext{
${ }^{22}$ Biuletyn Polityczny, nr 2-3, 1927, s. 675-681.

${ }^{23}$ Zob. Synarchista, nr 5, V 1929, s. 23.

${ }^{24}$ W. Roszkowski, op. cit., s. 273.

${ }^{25}$ Organizujcie Kluby Symarchistyczne, Synarchista, nr 3, XII 1934, s. 11.

${ }^{26}$ Uniwersal Synarchiczny, Synarchista, nr 3, V 1937, s. 1.

${ }^{27}$ Synarchista, nr 1, I 1938, s. 5 .

${ }^{28}$ Ibidem.
} 
swój akces wyraziła Radykalna Partia Chłopska, która połączyła się z założonym przez synarchistów Radykalnym Obozem Chłopskim.29. Przywódcą ROCh był Ludwik Maciag ${ }^{30}$. Wspólpraca z chłopami została przyjęta $z$ wielkim entuzjazmem na łamach ,Synarchisty", gdzie w artykule redakcyjnym napisano: „Szczególny oddźwięk idea synarchiczna znalazła na wsi: świadczy o tym szereg wielkich wieców i zebrań grup politycznych, ściśle $\mathrm{z}$ nami wspólpracujących jak Radykalnej Partii Chłopskiej, Radykalnego Obozu Chłopskiego i innych"31. 10 kwietnia 1938 roku synarchiści zorganizowali w Lublinie Wszechpolski Kongres Chłopski. Współpracę z związkiem nawiązała również Ukraińska Partia Agrama, Chliborobski Selanski Sojuz, a także grupa ślasskich działaczy Polskiej Partii Narodowo-Radykalnej, którzy powołali Ognisko Młodych Zwiazku Synarchicznego z Kazimierzem Goździńskim na czele. Ognisko Młodych Związku Synarchicznego w swej deklaracji programowej w sposób bardzo wyraźny nawiązywało do wskazań programowych zawartych w broszurze „Duch czasów nowych a Ruch Młodych" przywódcy Ruchu Narodowo-Radykalnego „Falanga" - Bolesława Piaseckiego. Ten działacz narodowo-radykalny pisaż ,[...] $w$ duszy młodego pokolenia istnieje też świadoma wola podporządkowania normom bezwzględnym, opartym na hierarchji wartości"32. Natomiast dzialacze Ogniska Miodych w Doklaracji Ideowej pisali: "Istota poglądów na świat mlodego pokolenia polskiego jest wiara $w$ istnienie hierarchii prawd bezwzględnych. Dożzość do ustalenia tej hierarchii jest cechą zasadniczą ducha czasów nowych"’3. Synarchiści w celu zwiększenia swych wpływów wśród robotników powołali swoją przybudówkę w tym środowisku - Obóz Robotniczy.

Dnia 12 lutego 1938 r. zawiązano Komitet Organizacyjny Wielkiej Rady Konfederacji Synarchicznej, zapowiadający „poddanie się obowiązkom organizacyjnym Związku Synarchicznego"; na przyszlego „wodza" Polski kreowany był już wyrażnie Tarło-Maziński (choć formalnie prezesem Konfederacji został J. Kurczyński) ${ }^{34}$. Wzmianki o powołaniu właśnie Tarło-Mazińskiego na przyszlego synarchę pojawiły się jednak jeszcze przed powołaniem konfederacji. W 1936 roku na łamach „Synarchisty”, rysując postać prezesa, pisano: „Zwiazzek Synarchiczny jest bardzo

${ }^{29} Z$ życia organizacji, Synarchista, nr 5,5 III 1938, s. 10.

${ }^{30}$ Chlopi a zycie puobliczne, Synarchista, nr 9, XI 1937, s. 12.

${ }^{31}$ Od redakcji, Synarchista, nr 9, X 1937, s. 1 .

${ }^{32}$ B. Piasecki, Duch czasów nowych a Ruch Mlodych, Warszawa 1935, s. 20.

${ }^{33}$ Deklaracja Ideowa Ogniska Mlodych Zwiazku Synarchicznego, Synarchista, nr 2, $8 \mathrm{I}, 1938$, s. 6.

${ }^{34}$ Synarchista, nr 5, 5 III 1938, s. 1. 
wymagający. Prezesem jego nie może być nikt inny, jak człowiek najlepszy, o jakim członkowie Związu w ogóle wiedza.. Jest to słowo wielkie oznacza ono człowieka, który jest siłaczem moralnie, bogaczem skarbami ducha, sławnym zasięgiem promieniowania swej indywidualności, wybitny twórczą praç myśli, niezłomnym wiarą w siebie, w współobywateli, w naród, w Polskę, w ludzkość. Dlatego prezesem Związku jest Tarło-Maziński" ${ }^{35}$. Ptzywódca związku w latach trzydziestych wykazywał się dużą aktywnością nie tylko jako autor szeregu odczytów w lokalu zwiazku, ale także jako inicjator przedsięwzięć mających nc celu wprowadzeniu nowych zwyczajów. Tarło-Maziński wyznaczył na dzień 2 maja nowe święto obchodzone przez działaczy związku - „Święto Synarchiczne"36.

W latach trzydziestych synarchiści opowiadali się w zasadzie za rządami sanacyjnymi, choć w artykułach pojawiala się także ich krytyka, której efektem była cenzura niektórych tekstów zamieszczanych $w$ organie związu. W roku 1934 z entuzjazmem przyjęli "Deklarację Ideową" Obozu Narodowo-Radykalnego, oraz wytyczne programowe Grupy Zwolenników Idei Jagiellońskiej, zauważając w tych dwóch programach wyraźne nawiązanie do synarchizmu ${ }^{37}$. Oczywiście stosunek ONR do synarchistów musiał być powściagliwy, wynikalo to przede wszystkim $\mathrm{z}$ faktu, iż Związek Synarchiczny kojarzony był z masonerią ${ }^{38}$. Na łamach periodyku związku co jakiś czas pojawiały się artykuly sygnalizujące niewątpliwe zbliżanie się momentu wprowadzenia nowego synarchicznego ustroju. W jednym $z$ takich tekstów publicysta pisma referuje kilka artykułów z prasy różnych proweniencji politycznych, a także przemówienie gen. Rydza-Śmigłego i rozkaz z okazji 16 rocznicy "Cudu nad Wisłą" gen. J. Hallera, dochodząc do wniosku, iż z treści artyłułów i przemówień wynika, iż w społeczeństwie coraz bardziej widoczna jest wola wspótpracy ${ }^{39}$. Jak już wspomniano, ogólny stosunek synarchistów do rząów sanacji był pozytywny. Po powstaniu Obozu Zjednoczenia Narodowego wyrażali chęć współpracy $\mathrm{z}$ obozem, o ile ten wprowadzi kilka zmian w swojej polityce i jeśli nie będzie likwidował partii politycznych. Te uważane były przez synarchistów za element wzbogacający

${ }^{35}$ Redakcja, Twórca synarchii. Z powodu 13 letniej rocznicy Zwiqzku Synarchicznego, Synarchista, nr 3, XI 1936, s. 2.

${ }^{36}$ Synarchista, nr 11, 30 IV 1938, s. 2; Przemówienie Prezesa Zwiqzku Synarchicznego na akademii 2 maja, Synarchista, nr 12, 4 VI 1938, s. 1.

${ }^{37}$ O krok od Synarchji, Synarchista, nr 2, VI 1934, s. $14-15$.

${ }^{38}$ W. Roszkowski, op. cit., s. 272.

${ }^{39}$ Zwiastun Konfederacji Synarchicznej, Synarchista, nr 3, XI 1936, s. 4-8. 
naród (poprzez tóżnice światopoglądowe i ścieranie się poglądów rozwijały się, według synarchistów, ,postęp i kultura"). Ponadto, aby współpracować z OZN, autor artykułu stwierdzał, iż należy naprawić krzywdy wyrządzone przez rządzących. Zauważał także, że zjednoczenie narodu może nastapić wyłącznie przez siłę moralna, a nie fizyczną. Proponował również, aby Obóz Zjednoczenia Narodowego przemianował się na „Warsztat Reparacji Rzeczypospolitej" ${ }^{\text {"40 }}$. Jak stusznie zauważył Wojciech Roszkowski, w swoim tekście wprowadzał ,[...] do ideologii synarchicznej nieco zamieszania twierdząc aforystycznie, iż «państwo bez opozycji to czlowiek, który nigdy nie patrzy w lustro», ale to nie było w koficu czymś nadzwyczajnym w ruchu, który gotów był godzić wszelkie sprzeczności, ${ }^{\text {,4l }}$. Należy dodać, iż $w$ innych publikacjach synarchiści opowiadali się za zmniejszeniem liczby partii politycznych, co było oczywiście pokłosiem ich założen, mówiących o tym, iż istnieja wyłącznie dwa obozy polityczne - prawica i lewica. W swojej publicystyce podkreślali oni wielokrotnie, iź partie polityczne reprezentują wyłącznie drobną część społeczeństwa. Twierdzili, iż: „Większość partii politycznych obecnie wyłącznie ubocznie zajmuje się polityką. Główne ich zajecie to przeprowadzanie na terenie partyjnym kosztem państwa i obywatela swoich interesów osobistych, a 96 partii to tylko 96 ambicji

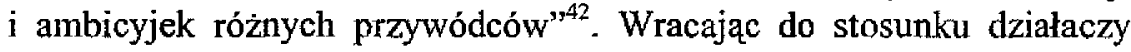
związku do Obozu Zjednoczenia Narodowego, warto przyjrzeć się opublikowanej w kilka miesięcy później, na łamach „Synarchisty”, ocenie powstania młodzieżowej przybudówki obozu - Związku Młodej Polski. Redakcja „Synarchisty" wypowiadala się w negatywnym tonie o tej organizacji. Wskazywała, iż z deklaracji ZMP nie wynika żaden program ,na

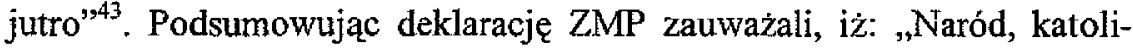
cyzm, antysemityzm, walka z masoneria. Ależ to stare hasła Narodowej Demokracji i Dmowskiego. Doceniamy rolę historyczną odegraną w swoim czasie przez ND i jej znakomitego wodza, ale to stara historia. To nie jest «Jutro». Jutro należy do tego, kto rozwiąże trzy naczelne, najpilniejsze problemy naszej obecnej polskiej rzeczywistości: 1) - dać pracę wszystkim polskim obywatelom i dać im dobrobyt, 2) - oprzeć Polskę na prawie i wolności, 3) - zabezpieczyć jej pokój i wielkomocarstwowość

${ }^{40}$ W. Roszkowski, op. cit, s. 272; G. Olechowski, Obóz Zjednoczenia Narodowego, Synarchista, nr 2, IV 1937, s. 4-9.

${ }^{41}$ Ibidem, s. 273.

${ }^{42}$ Synarchja w ustroju politycznym Polski, s. 20.

${ }^{43}$ Moda Polska, Synarchista, nr 6, VIII 1937, s. 1-3. 
przez unię z sąsiadami, mniejszymi natodami i państwami" "44. Jak widać, środowisko synarchistów nie miało sprecyzowanych pogląiów w stosunku do nacjonalistów, zważając na wcześniejsze pozytywne wzmianki o Obozie Narodowo-Radykalnym, a także przystapienie do Konfederacji Synarchicznej działaczy śląskiej Polskiej Partii Narodowo-Radykalnej.

Synarchiści mimo tego, iż przyszłego przywódcę państwa widzieli w osobie W. Tarło-Mazińskiego, starali się także kokietować władzę. W 1939 roku z okazji imienin Marszałka Rydza-Śmigłego, na pierwszej stronie „Synarchisty” redakcja opublikowała następujące życzenia: „Marszałkowi Edwardowi Śmigłemu-Rydzowi, w dniu Jego Imienin życzymy rychłego objęcia Naczelnego Dowództwa wszystkich sil zbrojnych Zjednoczonych Słowian i Państw Sojuszniczych. Niech żyje Armia Polska, Niech żyje Braterstwo Broni Ludów Słowiańskich, Królestwa Węgier i Rumunii" ${ }^{\prime 45}$.

Ciekawy jest stosunek synarchistów do projektów nowej konstyłucji. Jak twierdzili, ze względu na toczące się nad nią dyskusje, wydali na początku 1934 r. broszurę „Konstytucja synarchiczna, materiały, uzasadnienia i plan konstrukcyjny". Działacze zwiazzku widzieli w przedstawionych w sejmie 26 I 1934 r. tezach konstytucyjnych również własny wpływ ${ }^{46}$. Nie oznacza to jednak, iż przygotowywany przez sanację projekt nowej konstytucji został przyjęty bez zastrzeżeń przez działaczy związku. Mieczysław Wilbik zwracał uwage, iż w projekcie nowej konstytucji brak jest wyraźnego zaznaczenia celu państwa, poza tym brak powołania nowego ciała kierowniczego, jakie proponowali synarchiści - Rady Synarchicznej, a także zlekceważenie roli samorządu gospodarczego oraz brak dokładnego określenia zasad nowej ordynacji wyborczej (nowy projekt faktycznie całkowicie nie konstruowal nowej ordynacji, choć znalazły się w nim pewne wskazania, co do nowej ordynacji - nie zawierała między innymi zapisu o proporcjonalności wyborów, zmieniono wiek osób posiađających bierne $\mathrm{i}$ czynne prawo wyborcze, a także już w projekcie konstytucji zaznaczano, że 1/3 liczby senatorów wybierać będzie prezydent). Jednak mimo tych braków, Wilbik widział również pozytywy nowego projektu. Za najważniejsze uważal: wzmocnienie roli prezydenta (choć zauwaźał, że moźe nawet zbyt dużych), uniezależnienie rządu od sejmu i podporządkowanie go prezydentowi, podniesienie znaczenia elity

\footnotetext{
${ }^{44}$ Ibidem, s. 3.

${ }^{45}$ Synarchista, nr 4, 18 III 1939, s. 1.

${ }^{46}$ Synarchista, nr 1, IV 1934, s. 1.
} 
społecznej ${ }^{47}$. Synarchistów raził również brak odwołania w projekcie do kategorii narodu ${ }^{48}$. Główna krytyka projektów konstytucji była jednak spowodowana tym, iż synarchiści, w swoich planach zmian ustrojowych, szli znacznie dalej niż Stanisław Car i obóz sanacyjny.

Program Związu Synarchicznego można rozpatrywać w trzech płaszczyznach: filozoficznej, społeczno-politycznej i gospodarczej ${ }^{49}$. U podstaw programu filozoficznego synarchistów leżał pogląd mówiący, iż poprzez doskonalenie duchowe, dociekania rozumowe oraz syntezę różnych wartości można zrealizować ideę dobra i prawdy na ziemi ${ }^{50}$. Działacze Związku Synarchicznego, rozpoczynając wszelkie dywagacje na temat przyszłego ustroju Polski, zwracali uwagę, iż pierwszą i zasadniczą sprawa, która musi zostać wytyczona to „cel państwa”, na który musieliby się zgodzić wszyscy rozumni i uczciwi obywatele. Cel ten w programie politycznym formułowali następująco: „Celem tym jest rozwijanie w spoieczeństwie najwyższych zasad Prawdy i Dobra, aż do ich utożsamienia się w czynach obywateli" ${ }^{\prime 5 !}$. Niestety, bliżej nie definiowali, co rozumieli przez, ,Prawdę i Dobro". Jednocześnie zaznaczali, iż w celu osiagnięcia zasad „Prawdy i Dobra”, należy ustalić zasady moralnego postępowania. Pisali, iż „Moralność rozumiemy nie tylko w znaczeniu przestrzegania zakazów, lecz jako świadome i celowe dążenie do doskonałości wewnętrznej, warunkujące moralność społeczną" "J? Jeden z publicystów związku A. Leparski postulowal stworzenie Stowarzyszenia Moralnej Odbudowy Narodu. W ramach tego stowarzyszenia miały działać odpowiednie służby: etyki i moralności chrześcijańskiej, ładu i porządku społecznego, opinii (mającej za zadanie jej ujednolicanie), bezpieczeństwa, reform społeczno-ekonomiczny $\mathrm{ch}^{53}$.

Działacze zwiazku odwoływali się także do „filozofii rodzimej, polskiej" - czyli spuścizny intelektualnej Hoene-Wrońskiego ${ }^{54}$. Idealizowali także dzieje Polskij ${ }^{55}$. Ten zabieg mial szczególne znaczenie, ponieważ,

${ }^{47}$ Konstytucja kwietniowa na tle polskiej myśli politycznej, Synarchista, $\mathrm{nr} 1$, IV 1934 , s. 2-14.

${ }^{48}$ Brodzic-Lipiński, Konstytucja, Synarchista, nr 3, XII 1934, s. 3-4.

${ }^{49}$ W. Roszkowski, op. cit., s. 263.

${ }^{50}$ Ibidem, s. 263-264.

${ }^{51}$ Program polityczny Zwiqzku Synarchicznego, Synarchista nr 1, 15 X 1926, s. 2 .

${ }^{52}$ Synarchja w ustroju politycznym Polski, s. 21.

${ }^{53}$ W. Roszkowski, op. cit., s. 268.

${ }^{54}$ Swoi i obcy, Synarchista, nr 1, IV 1933, s. 6.

${ }^{55}$ Konstytucja Synarchiczna, Warszawa 1934, s. 14. 
wedhug wskazań synarchistów, to Polska właśnie miała być ze swym nowym ustrojem ratunkiem dla Europy, która, według działaczy związku, znajduje się „w katastrofalnym kryzysie ekonomicznym i politycznym, nie widząc rozumnego wyjścia, idzie ku przepaści anarchii, lub niemniej zgubnego krępowania rozwoju społeczeństw, skazując je tym samem na zwyrodnienie"56. „Opatrznościowe posłannictwo", jakie nadawali Polsce synarchiści, miało wyraźnie mesjanistyczne podstawy.

Działacze zwiazku opowiadali się przeciw materializmowi. Głosili, iż celem najwyższym człowieka jest prawda i dobro. Publicysta Mieczysław Wielbik pisał: „Od tych kresów [świata materialnego - P. T.] dzieli nas jeszcze być może wielki okres czasu - stałego opanowania materii przez ducha i ten okres to właśnie czas działania Synarchji, czas zdobywania Prawdy i stworzenia Dobra. Wyrażać się on będzie $z$ jednej strony $w$ doskonaleniu się moralnem istot ludzkich, $z$ drugiej zaś strony $w$ rozwoju prawdziwej wiedzy i nauki”,57. Ponadto, autor tych słów darzył ogromnym zaufaniem naukę, która, według niego, w nowym ustroju będzie obejmowała takie dziedziny, które dotychczas są dla niej nieosiagalne, przez co będzie mogła thumaczyć cały szereg zjawisk, a nawet „pozwoli również sięgnąć w daleką przyszłość i wykreślić drogę rozwoju zarówno wszechświata i ludzkości, jak i dla każdej jednostki ludzkiej"ss. Dzięki tak rozwiniętej nauce $i$ możności prognozowania przyszłości znikłoby ryzyko w gospodarce. Poza tym, jak zauważał Wielbik, zastosowanie zdobyczy nauki wykorzystywane byłoby w „doborze małżeństw", a nawet „uszlachetnianiu rasy"59. Trudno stwierdzić, w jaki sposób rządy rozumu miałyby dać się pogodzić z wolnością jednostki, o której tak często pisali synarchiści ${ }^{60}$.

W stosunku do religii działacze zwiazku doceniali znaczenie chrześcijaństwa. Uważali, iż: „Treść chrystianizmu, głoszącego Boskie posłannictwo człowieka i równość ludzi, przenoszącego treść praw i obowiązków do życia wewnętrznego - posiada wieczną żywotność"61. Jednocześnie opowiadali się za rozdziałem Kościoła od państwa. Podkre-

${ }^{56}$ Synarchja w ustroju politycznym Polski, s. 54.

${ }^{57}$ M. Wielbik, Rzut oka na przyszlość ustroju synarchicznego, Warszawa 1932 , s. 22.

${ }_{58}^{58}$ Ibidem, s. 24.

${ }^{59}$ Ibidem, s. 25.

${ }^{60} \mathrm{~W}$. Roszkowski, op. cit., s. 264.

${ }^{61}$ Uniwersat Synarchiczny, Warszawa 1937, s. 5. 
ślali, iż państwo gwarantować powinno kaźdej religii swobodny rozwój kultu religijnego, a także wolność głoszenia zasad religijnych ${ }^{62}$.

\section{Ustrój}

Przyglądając się dwóm prądom ideowym, jakie bujnie rozwijały się w Europie międzywojennej - komunizmowi i faszyzmowi, synarchiści konstatowali, że opierają się wyłącznie na jednym biegunie politycznym - lewicy bądź prawicy, przez co skazane są w przyszlości na upadek. Wyjściem z sytuacji - zdaniem synarchistów - byłoby oparcie się na syntezie tych dwóch nurtów politycznych ${ }^{63}$. Taki synkretyczny model ustroju proponował w swych enuncjacjach związek.

Synarchiści opowiadali się za nadaniem szczególnych uprawnień obieranemu dożywotnio Naczelnikowi Państwa (określanemu także zamiennie mianem Synarchy), który miał łączyć ,funkcje władzy monarszej i republikańskiej, a mianowicie dekretowania $z$ mocą ustawy" ${ }^{964}$. Synarcha, wedhug założeń ustrojowych zwiazku, miałby prawo nominacji szefa rządu, ministrów i podległych im urzędników. Obowiązywałaby zasada bezpośredniej odpowiedzialności zwierzchników za pracę podwładnych (podobną hierarchiczną propozycję odpowiedzialności w swoim programie zawarli działacze ONR). Rząd pelniłby władzę wykonawcza, przy czym zakładano rozdział funkcji rządowych na: wewnętrzne premier, zewnętrzne - kanclerz, wojskowe - hetman ${ }^{65}$. Synarchę wybieraloby Zgromadzenie Narodowe. Kandydatów na ten urząd proponowałoby cialo „opiniodawcze Rządu i Narodu" - Rada Synarchiczna. W skład Rady Synarchicznej wchodziłby także synarcha. W Radzie zasiadać mieli bliżej nieokreśleni obywatele, „władający rozwiązaniami synarchicznymi" ${ }^{\prime \prime}$. Moglo to prowadzić do oczywistych nadużyć. Jak wiele innych określeń, „władający rozwiązaniami synarchicznymi” można było bowiem

${ }^{62}$ Ibidem, s. 34-35.

${ }^{63}$ Swoi i obcy, ,Synarchista", nr 1, IV 1933, s. 6

${ }^{64}$ Program polityczny Zwiazku Synarchicznego, s. 3. W latach dwudziestych z synarchistami na tematy ustrojowe prowadzili polemiki monarchiści Rozmowa z Synarchistami, Nowa Polska, 1 I 1928; Do Zwiazku Synarchistów, Pro Patria, 1928, nr 140. Również działacze związku odpowiadali monarchistom. Zob. Monarchizm nowoczesny, czy nowoczesność interpretacji monarchizmu, Synarchista, nr 4, VII 1928, s. 17.

${ }^{65}$ Program polityczny Zwiqzku Synarchicznego, s. 3.

${ }^{66}$ Ibidem. 
różnorako interpretować. Ostatecznie Rada Synarchiczna mogła być ciałem zupełnie hermetycznym. Rada kierowałaby całością spraw państwowych. Sejm i Senat, według projektów synarchistów, miały być wyłącznie ciałami prawodawczymi. Senatowi miała przypadać rola izby, w której sprawdzano by, czy dana ustawa działa w kierunku potęgowania $w$ narodzie świadomości narodowej i zasad moralnych ${ }^{67}$. W razie konfliktu pomiędzy dwoma izbami parlamentu, ostateczne rozstrzygnięcie miało należeć do posiadającego ogromne prerogatywy Naczelnika Państwa ${ }^{68}$. Działacze związku, w swoich wskazaniach programowych, przyjmowali hipotetycznie możliwość konfliktu pomiędzy Naczelnikiem Państwa a Sejmem, gdzie ten ostatni względem Naczelnika występuje z votum nieufności. W takiej sytuacji Naczelnik Państwa miał rozwinzać Sejm, a następnie „odwołać się w orędziu do Narodu jako do formalnego źródła swej władzy, wyznaczając natychmiast wybory do następnego sejmu"69. Jeźeli kolejny Sejm, wybrany po zapoznaniu się wyborców $z$ orędziem Naczelnika, nadal wyraża $w$ stosunku do niego votum nieufności, ten musi zgodzić się ze stanowiskiem Sejmu lub też ustąpić. W ostatnim wypadku Zgromadzenie Narodowe powołuje nowego Synarche $e^{70}$. Funkcje kontrolne posiadałyby powołane przy Radzie Synarchicznej Izby Państwowe. Dzieliłyby się na: 1) lzbę podań (sprawiedliwości podatkowej; 2) Izbę zażaleń (sprawiedliwości administracyjnej); 3) Izbę kasacyjną (sprawiedliwości sądowej); 4) Izbę kapituły (sprawiedliwości urzędniczej, odpowiedzialną za wydawanie nominacji, dyplomów $)^{71}$. Ponadto Radzie Synarchicznej podlegatyby jeszcze trzy kolejne Izby (obrachunkowe) - statystyczna, celowości i postępów ${ }^{72}$, które pełnilyby rolę podobną do ośrodka badania opinii publicznej.

Rada Synarchiczna, przez „,bezpośrednie obserwacje” oraz na podstawie danych Izb obrachunkowych, określałaby kierunek polityki państwa. Opinie Rady kierowane byłyby do Rady Ministrów, która opracowywałaby projekty ustaw, a następnie przesyłała je do sejmu lub senatu (obie izby ciała ustawodawczego byłyby dwubiegunowe). Jeżeli ustawa zostałaby przyjęta przez Sejm, przechodziłaby do Kancelarii państwowej, aby uzyskać podpis Naczelnika Państwa ${ }^{73}$. Nastęnie ustawa przechodziłaby

\footnotetext{
${ }^{67}$ Co to jest synarchja, Warszawa 1925, s. 11.

${ }^{68}$ Synarchja w ustroju politycznym Polski, s. 43.

${ }^{69}$ Ibidem, s. 43-44.

${ }^{70}$ Ibidem, s. 44.

${ }^{71}$ Co to jest synarchja, s. 9.

72 Ibidem, s. 10.

${ }^{73}$ Synarchja w ustroju politycznym Polski, s. 42.
} 
do odpowieảniego ministerstwa, odpowiedzialnego za jej wykonanie ${ }^{74}$. Bezpośrednio Naczelnikowi Państwa podlegałaby nie tylko Kancelaria Państwa, ale również Sekretariat Państwa, zajmujący się komunikacją z Sejmem, Senatem i Radą Ministrów oraz Gabinet Naczelnika Państwa, z którego wychodzić miały dekrety nominacyjne, mianujące urzędników, członków Rady Synarchicznej i lzb ${ }^{75}$.

Związek Synarchiczny opowiadał się za bezpośrednim głosowaniem do rad gmin i miast na bezpartyjnych kandydatów. Uzasadnieniem wyboזów bezpośrednich na bezpartyjnych kandydatów byl, według synarchistów, fakt, iż tylko mniejszość społeczeństwa należała do partii politycznych $^{76}$. Proponowano wertykalną strukturę wyborcza, gdzie wybrani przedstawiciele $\mathrm{z}$ rad gmin głosowaliby na przedstawicieli do rad powiatów, zaś powiaty wybicralyby przedstawicieli do sejmu. Zasada takiego obierania przedstawicieli byla zgodna $z$ ideq hierarchiczności. Pozostali, nie wybrani do Sejmu członkowie rady powiatu, tworzyć mieli Radę poselska. Ta miałaby możliwość ilością 3/4 głosów wyrazić votum nieufności wobec posła, który wtedy musialby ustapić ${ }^{77}$. W Senacie zasiadać miały osoby wybrane ,[...] z łona Narodu ewolucyjną droga, powszechnego uznania". Liczba miejsc i urzędów, dzięki którym przysługiwałby tytuł Senatora, miała być określona ustawowo ${ }^{78}$. Członkowie Senatu zatwierdzani mieli być przez Synarchę ${ }^{79}$. Senatorami miały zostać osoby posiadające wysokie stanowisko naukowe, społeczne, urzędowe lub kościelne ${ }^{80}$.

W ustroju synarchicznym zapewniona miała być niezawisłość sądownictwa, choć sędziów, po przedstawieniu do nominacji przez organizacje sądownicze, działające w porozumieniu z Ministrem Sprawiedliwości, mianować mial Synarcha ${ }^{81}$.

Związek Synarchiczny opowiadał się również za jak najbardziej rozwiniętym i zróżnicowanym samorządem. Miał to zatem być zarówno samorząd terytorialny jak i gospodarczy, a także narodowościowy. Najniższym szczeblem władzy w państwie miała być samorządowa gmina. Dzięki wprowadzeniu wertykalnego prawa wyborczego władze lokalne

${ }^{74}$ Co to jest synarchja, s. 15.

${ }^{75}$ Synarchja w ustroju politycznym polski, s. 44.

${ }^{70}$ Co to jest synarchja, Warszawa 1925, s. 18.

77 Ibidem, s. 19.

${ }^{78}$ Ibidem, s. 11.

${ }^{79}$ S. Gaszyński, Do czego dqżymy, Synarchista nr 1,15 X 1926, s. 7.

${ }^{80}$ Co to jest synarchja, s. 11.

${ }^{81}$ Synarchja w ustroju politycznym Polski, s. 44. 
niższego rzędu uczestniczyłyby w wyłanianiu władz wyższego szczebla. Dzięki temu zabiegowi władza samorządowa bylaby powiązana $\mathrm{z}$ władzami ogólnopaństwowymi ${ }^{82}$.

\section{Gospodarka}

Kwestie gospodarcze zajmowały istotne miejsce w myśli politycznej Związku Synarchicznego. W celu naprawy gospodarki kraju synarchiści proponowali gruntowne zmiany. Program ten został rozwinięty przez Komisje Finansową Zwiazzku. Opracowany był przy wspóhudziale A. Doermana, M. Hoffa, S. Jabłońskiego, W. Kalabińskiego, L. Mikołajczaka, a przede wszystkim Feliksa Sobolewskiego ${ }^{83}$.

Synarchiści, podobnie jak Hoene-Wroński, uważali, iż pieniądz posiada trzy podstawowe zadania: 1) jest miernikiem wartości, 2) środkiem porównawczo-wymiennym, 3) środkiem przechowywania wartości ${ }^{84}$.

Podstawową zmiana, która propagowali, było odejście od złota jako jednostki obliczeniowej, a tym samym, odejście od uzaleźnienia emisji pieniądza od pokrycia tegoż w zasobach kruszcu ${ }^{85}$. Rozwiązanie to miało wprowadzić obiektywny podział zysków pomiędzy kapitał a pracę, proponowano zastapienie pieniądza opartego o złoto i wprowadzenie stałej Towarowej Jednostki Obliczeniowej, określonej na podstawie 17 produktów pierwszej potrzeby takich, jak np.: chieb, mąka, kasza, cukier, masło, mleko, ziemniaki, wegiel, drzewo ${ }^{86}$. Towarową Jednostke Obliczeniowa nazywano dla ułatwienia „polonem",87. Jeden „polon”, dzieliłby się na sto setnych, stanowiłby on równowartość np. $238,59 \mathrm{gr}$ chleba, $125,63 \mathrm{gr}$ mąki pszennej, 90,58 gr fasoli, 52,51 gr mydla ${ }^{88}$. „Polon” pehnić miał więc funkcję miernika wartości oraz środka przechowywania wartości. Inaczej natomiast miała się sprawa $\mathrm{z}$ funkcją porównawczo-wymienną pieniądza. Według synarchistów, skoro dotychczas używany pieniądz był fałszywym miernikiem wartości i nie posiadał zdolności przechowywania jej niezmiennie, nie mógł być również odpowiednim środkiem porów-

\footnotetext{
${ }^{82}$ Uniwersal synarchiczny, s. 32.

${ }^{83}$ Zarys synarchicznej reformy ustroju pienięznego, Warszawa 1938, s. 30.

${ }^{34}$ Synarchiczna reforma gospodarcza, Warszawa 1927, s. 33.

${ }^{85}$ Ibidem, s. 10.

${ }^{86}$ Ibidem, s. 13-14, 20-21, 36-37.

${ }^{87}$ Ibidem, s. 36-37.

${ }^{88}$ Zarys synarchicznej reformy ustroju pieniężnego, s. 80.
} 
nawczo-wymiennym ${ }^{89}$. Tę ostatnią funkcję miał petnić Znak Obiegowy, nazwany umownie ,piastem". Miałby on właściwości inne od „polona”. Piast posiadałby funkcje niezmienne, służąc jako miernik do oszacowywania innych wartości. Natomiast emisja „piastów" miała być dostosowana do pokrycia w wartościach zmiennych, takich jak wielkość plonów. Wartość Znaku Obiegowego w stosunku do Towarowej Jednostki Obliczeniowej miał ustalać i podawać do publicznej wiadomości Główny Urząd Statystyczny ${ }^{90}$. Synarchiści chcieli doprowadzić do sytuacji, w której wszelkie operacje kupna - sprzedaży, oszczędzania, układania budżetu opierałyby się na „połonach”, natomiast wypłaty wynagrodzeń (po kursie dnia) na "piastach" ${ }^{\text {"9 }}$. Emisji „piasta" dokonywałby Państwowy Instytut Emisyjny, który zastapiłby Bank Narodowy ${ }^{92}$. Wraz ze zwiększeniem produkcji krajowej zwiększałby się natychmiastowo wzrost ilości „polonów”, a co za tym idzie, również „piastów”. Przyglądając się propozycjom finansowym synarchistów nasuwa się pytanie, w jaki sposób odbywalby się handel międzynarodowy? Synarchiści odpowiadali na to pytanie następujaco: „Przypatrzmy sie obecnie, jak wprowadzenie u nas waluty, nie opartej o złoto, odbije się na naszych stosunkach z zagranicą $\mathrm{i}$ jakie stąd wynikać mogą następstwa dla naszego życia gospodarczego. Stwierdziliśmy wyżej, że zobowiazania nasze wobec zagranicy płacimy $w$ walucie obcej i że należność za wymienione przez nas produkty przyjmujemy przekazani również $\mathrm{w}$ walucie obcej, nie domagając się od zagranicy, by obecną walutę naszą uważala za środek płatniczy równy swojemu. [...] W tym stanie rzeczy zmiana systemu walutowego w nas żadnych perturbacji, które moglyby się odbić niekorzystnie na naszym wywozie, wywolać nie jest w stanie" ${ }^{\text {"93 }}$. System pieniężny propagowany przez Związek Synarchiczny miał zasadnicze niedociągnięcia - jak np. autorytatywne ustalanie kursu „piasta" w sto-

${ }^{89}$ Synarchiczna reforma gospodarcza, s. 34.

${ }^{90}$ Ibidem, s. 38. Czasami dzialacze zwiazzku pisali, iż wielkością emisji Znaku Obiegowego ma się zajmować Instytut Celowości Gospodarczej (w publicystyce synarchistów spotykało się również nazwę Instytut Celowości Ekonomicznej). Zob. Wytyczne synarchicznego programu gospodarczego, Synarchista, nr 2, VI 1934, s. 12.

${ }_{91}$ Zarys synarchicznej reformy ustroju pieniężnego, s. 52-54; A. Roszkowski, op. cit., s. 271.

${ }^{92}$ Zarys synarchicznej reformy ustroju pieniężnego, s. 62, 72.
${ }^{93}$ lbidem, s. 68 . 
sunku do „polona", który w zależności od wytycznych Głównego Urzędu Statystycżnego kształtować się mógł na poziomie nierealnym ${ }^{94}$.

Synarchiści uważali, iż: „Praca i Kapitał muszą być równouprawnione $w$ znaczeniu założenia pomiędzy nimi właściwego stosunku. W tym celu należało wyzwolić pracę, która obecnie jest niewolnikiem kapitału, kapitał zaś uczynić narzędziem pracy"95. Proponowali więc równy podział zysków ${ }^{96}$. Podział zysków miał nastapić po odjęciu amortyzacji i dywidend, według ,kapitału pracy", wyłożonego przez pracowników etatowych. "Kapital pracy” mial być określony wedhug pobieranego wynagrodzenia. Model tego rozwiazania nawiązywał do koncepcji "solidarystycznej i syndykalistycznej"97.

Według działaczy związku, w momencie zapewnienia każdemu obywatelowi miejsca pracy oraz mieszkania, zniknie proletariat jako grupa społeczna $^{98}$. Aby zapewnić każdemu obywatelowi miejsce pracy i przyśpieszyć wzrost gospodarczy, synarchiści proponowali zorganizowanie pracy na zasadach prawa wlasności indywidualnej przy centralnym kierownictwie paŕstwa. Związek chciał powolać Instytut Celowości Gospodarczej, do którego zadań należałoby badanie potrzeb gospodarczych spoleczeństwa. Miało to doprowadzić do „racjonalnego zorganizowania produkcji”, a także "utrzymanie stałej harmonii pomiędzy konsumpcja a produkcją ${ }^{99}$.

Działacze związku negatywnie oceniali system kredytowy określając go jako spekulacyjny. Ówczesną sytuację opisywali następująco: ,[...] współczesny kređyt, jako narzędzie pieniądza i kapitahu, aż nazbyt często rozmija się ze swoim powołaniem, całkowicie oddając się $\mathrm{w}$ ręce tych ostatnich. Wynikiem zaś takiej służby kapitału jest pasożytnictwo jednostek kosztem tysięcy wraz $\mathrm{z}$ jego zdyskredytowaniem oraz ułatwieniem powstania możnowładztwa międzynarodowej finansjery, która już wywiera decydujący wpływ na układanie się stosunków i bieg dziejów, a której ambicje sięgają do całkowitego opanowania i ujarzmienia świata"100. Proponowali więc, aby system ten został upaństwowiony ${ }^{101}$.

94 W. Roszkowski, op. cit., s. 271.

95 Program polityczny Zwiazku Synarchicznego, Synarchista, nr 1, 15 X 1926, s. 3.

${ }^{96}$ W. Roszkowski, op. cit., s. 272.

${ }^{97}$ Ibidem.

${ }^{98}$ Co to jest synarchja, s. 16.

${ }^{99}$ F. Sobolewski, Wytyczne planu gospodarczego, Synarchista, nr 2, 14 IV 1927, s. 7.

${ }^{100}$ Co to jest synarchja?, s. 29. 
Kredyty miały być niskooprocentowane, dzięki czemu gospodarka miakaby się szybko rozwijać ${ }^{102}$.

Synarchiści byli zwolennikami autarkii gospodarczej. Uważali, że dużą częsć potrzeb gospodarczych kraju zaspokoją sami ${ }^{103}$. W handlu zagranicznym proponowali, aby Polska wymieniała jedynie nadwyżki produkcyjne na towary, których w kraju się nie wytwarza ${ }^{104}$. Generalnie opowiadali się także za wprowadzeniem sporej ilości monopoli panstwowych. Państwo miało się więc zajmować wyłącznie handlem z zagranica, proponowano nawet wprowadzić monopol zbożowy. Naleźy zwrócić uwagę na fakt, iż działacze związku występowali z krytyką międzynarodowego kapitału, któty najczęsciej krytykowany był przez ugrupowania nacjonalistyczne za swe powiązania $z$ masonerią.

W dziedzinie gospodarki postulowano szeroko zakrojone roboty publiczne. $W$ ich ramach pianowano osuszyć błota oraz rozpoczać budowę kanału wodnego łaczacego Gómy Ślask z Bałtykiem. Wskazywano na potrzebę modernizacji rolnictwa, m.in.: poprzez meliorację a także osuszanie błot $i$ bagien na kresach wschodnich ${ }^{105}$. Ponadto planowano elektryfikacje, budowe gazowni, wodociqgów i kanalizacji ${ }^{106}$. W celu zrealizowania tych zamierzeń proponowano wprowadzić dziesięcioletni plan gospodarczy ${ }^{107}$. W sferze rolnictwa Związek Synarchiczny opowiadał się $z$ jednej strony za zintensyfikowaniem produkcji tolnej, z drugiej zaś za rozwojem gałęzi pokrewnych, jak handel produktami rolnymi ${ }^{108}$.

Podatki, według synarchistów, miały zostać uproszczone. Przewidywano wprowadzenie trzech podatków: a) wykup patentów 1) przemysłowych, 2) handlowych, 3) zawodowych, b) podatek od zysków z przedsiębiorstw przemyslowych, rolnych i handlowych, c) podatek od zysków od majątku nieruchomego. Poza tym państwo czerpałoby dochody: 1) z mo-

${ }^{101}$ Ibidem, s. 29.

102 Zarys synarchicznej reformy ustroju pienięznego, s. 54.

103 Ibidem, s. 17.

${ }^{104}$ Uniwersal Synarchiczny, s. 26.

${ }^{105}$ F. Sobolewski, Wytyczne planu gospodarczego, gospodarczego, s. 7.

${ }^{106}$ Wytyczne synarchicznego plonu gospodarczego, Synarchista, nr 2, VI 1934, s. 12 .

${ }^{107}$ Zet, Zagadnienie robót publicznych czy zagadnienie generalnego rozwiqzania aktywizacji życia gospodarczego w Polsce, Synarchista, nt 6, VIII 1937, s. $4-6$.

${ }^{108}$ Jotka, Cel gospodarczy wsi naszej, Synarchista, nr 3, V 1937, s. 12. 
nopoli, 2) ze stempli, 3) z cel, 4) z dóbr i przedsiębiorstw państwowych $^{109}$.

Handel, podobnie jak i inne dziedziny gospodarki, miał się opierać na kupiectwie rodzimym ${ }^{110}$. W tej dziedzinie gospodarki nie zakładano planowości, ponieważ synarchiści zauważali zależność występującą pomiędzy konkurencja a ceną towaru ${ }^{11}$.

\section{Zagadnienia spoleczne}

Synarchiści $w$ swoim programie proponowali walkę $\mathrm{z}$ analfabetyzmem, a także podniesienie oświaty publicznej. Opowiadali się za całkowitym bezpłatnym dostępem do nauki ${ }^{112}$.

Mieszkania komunalne mialy zostać przejęte przez specjalnie zorganizowany fundusz mieszkaniowy, którego członkiem miały zostać wszystkie miasta. Chciano wprowadzić następującą zasadę: „domy czynszowe należą do gmin miejskich, lokatorzy są użytkownikami, a przez udział we własności społecznej współwłaścicielami" ${ }^{113}$. Jeden z publicystów związku Gustaw Olechowski proponowal, aby osoby wynajmujące mieszkania, po okresie spłacenia jego ceny wraz $\mathrm{z}$ należąca się właścicielowi amortyzacją oraz pewnym procentem zysku, stawali się właścicielami mieszkania (autor artykułu zakładał, iż wszyscy wynajmujący mieszkania W kamienicy postępuja podobnie, to znaczy splacają mieszkania). Właściciel miał po uzyskaniu zwrotu za poniesione koszty możliwość budowy kolejnej kamienicy ${ }^{114}$.

Ponadto zwiazek opowiadal się za powszechnym systemem ubezpieczeń spolecznych, nad którym kontrolę sprawowałby ogólnokrajowy Instytut Ubezpieczeń Spolecznych ${ }^{115}$.

Odrębnym zagadnieniem jest stosunek synarchistów do mniejszości narodowych. Uważali oni, iż muszą one mieć zapewnioną ochronę w dziedzinie rozwoju własnej kultury narodowej. Szczególnie pozytywnie synarchiści wypowiadali się o mniejszościach słowiańskich. Uważali, iż wprowadzenie samorządu mniejszości narodowych rozładuje napięcia

\footnotetext{
${ }^{109}$ F. Sobolewski, Wytyczne plant gospodarczego, s. 7-8.

${ }^{110}$ Co to jest synarchja?, s. 17.

"11 Zarys synarchicznej reformy ustroju pieniężnego, s. 54.

${ }^{112}$ Uniwersal Synarchiczny, s, 28.

113 Ibidem, s. 30.

${ }^{114}$ G. Ol, Sprawa mieszkaniowa, Synarchista, nr 4, VI 1937, s. 9.

${ }^{115}$ Uniwersal Synarchiczny, s. 30.
} 
pomiędzy nimi a Polakami. W stosunku do Żydów, w „Uniwersale Synarchicznym, wyrażali następująca opinię: „Przebudowa struktury ekonomiczno-społecznej umoźliwi i ułatwi oczyszczenie wszelkich dziedzin życia polskiego od tych elementów, obcych duchowi polskiemu i charakterowi narodowemu, przeciwko którym buntuje się instynkt samozachowawczy najszerszych mas społecznych. Umożliwiając i popierając, a nawet przyśpieszając emigracje tych żywiołów żydowskich, których działalność gospodarcza jest szkodliwa [...]"116. Zaznaczali także, że część Żydów, która zorganizuje się jako mniejszość narodowa (w autonomicznym gospodarczo i społecznie organizmie, jakim miał być samorząd narodowy), zostanie objęta pełnymi prawami i opieką państwa ${ }^{17}$. Poza enuncjacjami zawartymi w uniwersale, synarchiści wypowiadali się sporadycznie na temat Żydów. W artykule „To nie nasze zmartwienie" z 1937 roku pisali, iż nie poświęcają miejsca sprawom tej mniejszości, ponieważ zajmują się na łamach „Synarchisty” problemami Polaków, a nie Żydów, gdyż jest to problem narodu żydowskiego ${ }^{118}$.

\section{Polityka zagraniczna}

Synarchiści opowiadali się za zwiększeniem roli Ligi Narodów, chcieli powołania Federacji Państw Słowiańskich, docelowo zaś Federacji Wszechnarodowej ${ }^{119}$. W latach trzydziestych zwiększyla się ilość akcentów panslawistycznych. Na pierwszej stronie swego periodyku synarchiści pisali o misji dziejowej Polski, jaką było, według nich, zjednoczenie słowiańszczyzny. Pisali: „Jedynie hasło zjednoczenia słowiańszczyzny - tej najmłodszej rasy o niezmierzonych możliwościach rozwojowych, proklamowane przez twórcę ruchu synarchicznego, Włodzimierza Tarło-Mazińskiego, w imię wspólnego rozwoju politycznego, moralnego i gospodarczego wyzwolenia się $\mathrm{z}$ jarzma międzynarodowego kapitału" ${ }^{i 20}$. Wyrażali także nadzieję, że Słowacja wejdzie w przyszłości do kierowanego przez Polskę bloku państw słowiańskich. Liczono rów-

${ }^{116}$ Ibidem, s. 36.
${ }_{117}$ Ibidem.
${ }_{118}$ To nie nasze zmartwienie, Synarchista, nr 7, IX 1937, s. 14.
${ }_{119}$ Program polityczny Zwiqzku Synarchicznego, Synarchista, nr 1, 15 XI 1926, s. 3.

${ }^{120}$ Zjednoczenie Slowiańszczyzny misja dziejowa Polski, Synarchista, nr 8-9, 26 III 1938, s. 1. 
nież, że do tego bloku przyłączą się niesłowiańskie Węry ${ }^{121}$. O sojuszu państw słowiańskich pisano nawet wówczas, gdy po zajęciu przez Hitlera Czech stało się jasne, że konflikt zbrojny jest bardzo bliski, a powstanie sojuszu państw słowiańskich jest w ówczesnej sytuacji międzynarodowej nierealne. W enuncjacjach synarchistów pojawiały się także akcenty pacyfistyczne.

Działalność polityczna Związku Synarchicznego skupiała się przez cały okres dwudziestolecia międzywojennego głównie na próbach zdobycia szerszych wpływów politycznych. Przynosiło to jednak mizerne efekty, biorąc pod uwage nawet pewne sukcesy organizacyjne synarchistów związane $z$ powstaniem Konfederacji Synarchicznej.

Myśl polityczna związku jest bardzo interesująca. Poprzez próby połączenia poglądów lewicowych z prawicowymi, synarchiści nawiązywali w swoich enuncjacjach zarówno do nauki społecznej Kościoła, jak i poglądów syndykalistycznych. W rozwiązaniach ustrojowych było widać wpływy koncepcji odwołujących się do hierarchii społecznej i elitaryzmu. W koncepcjach gospodarczych proponowali wprowadzenie centralnego planowania oraz upaństwowienia głównych gałęzi gospodarki. W tych zagadnieniach wykazywali pewne podobieństwo do poglądów, nie tylko komunizujących grup politycznych, ale również w pewnym stopniu do programu gospodarczego Ruchu Narodowo-Radykalnego, czy też środowiska skupionego wokół pisma ,Zadruga". Ponadto znajdujemy sporo odwołań do koncepcji mesjanistycznych polskich romantyków.

Mimo deklaracji synarchistów mówiących o potrzebie godzenia wzajemnych sprzeczności - program polityczny przez nich reprezentowany $w$ wielu miejscach wzajemnie się wykluczał. Wiele $\mathrm{z}$ tez było nierealnych i pozbawionych jakiegokolwiek umocowania w rzeczywistości, jak miało to miejsce np. w programie polityki zagranicznej Polski. Wyđaje się, że również w stosunku do rządów pomajowych, jak $\mathrm{i}$ innych stronnictw politycznych, synarchiści mieli problemy $z$ wykrystalizowaniem jednoznacznego stanowiska.

Ciekawy jest również rodowód przywódców związku, którzy wywodzili się z kręgów masonerii okultystycznej. Te inspiracje dawały się także odczuć w niektórych tezach programowych, choć przeplatały się one także $z$ nawiqzzaniami do myśli nacjonalistycznej.

${ }^{121}$ G, S., Waga granicy Polsko-Wegierskiej, Synarchista, nr 4, 18 III 1938, s. 3. 
Na pewno Związek Synarchiczny stanowił jedno $z$ bardziej oryginalnych środowisk politycznych II RP. W podobnym tonie do synarchistów utrzymany był program polityczny poznańskiego Związku Irenistów. 